\title{
ORYGINALNOŚĆ HIEROKLESOWEGO PORÓWNANIA APOLONIUSZA Z TIANY Z CHRYSTUSEM
}

Zaraz na początku tzw. „,wielkiego prześladowania” wyznawców Chrystusa, a więc w 303 r., Sossianus Hierokles opublikował antychrześcijański traktat pt. Przyjaciel prawdy ( usprawiedliwienie dla represji wobec chrześcijan, które sam autor podejmował jako namiestnik Bitynii i zarazem doradca cesarski. Dzieło tego wysokiego urzędnika cesarza Dioklecjana nie zachowało się do naszych czasów; nie znamy zatem dokładnie ani jego układu, ani rozmiarów. O jego treści zaś dowiadujemy się z pism Laktancjusza i Euzebiusza z Cezarei, którzy z pozycji chrześcijańskiej przeprowadzili ostrą polemikę z wywodami Hieroklesa, prezentując zarazem jego argumentację i cytując niektóre fragmenty jego traktatu ${ }^{1}$. Autor Przyjaciela prawdy kontynuował w swoim piśmie wrogą chrześcijaństwu tradycję filozoficzną, a także uciekał się do argumentów i oskarżeń z wcześniejszej polemiki antychrześcijańskiej.

1. Świadectwo Euzebiusza z Cezarei. Był jednak pewien aspekt zupełnie oryginalny $\mathrm{w}$ jego argumentacji, na który zwraca uwagę Euzebiusz stwierdzając, że Hierokles ,jako jedyny wśród tych, którzy kiedykolwiek wystąpili przeciwko nam na piśmie, dokonał niedawno specjalnego zestawienia i porównania tegoż męża [Apoloniusza z Tiany] z naszym Zbawicielem"2. To właśnie owo porównanie Apoloniusza z Chrystusem, które przeprowadził Hierokles, wydało się Euzebiuszowi z Cezarei czymś zupełnie nowym

\footnotetext{
* Ks. dr Adam Tondera - adiunkt w Katedrze Teologii Patrystycznej i Historii Kościoła na Wydziale Teologicznym Uniwersytetu Śląskiego; e-mail: atondera@poczta.onet.pl.

${ }^{1} \mathrm{Na}$ temat kariery Hieroklesa i treści Przyjaciela prawdy zob. A. Tondera, „Przyjaciel prawdy" Sossianusa Hieroklesa, SSHT 46 (2013) fasc. 2, 303-316; W. Speyer, Hierokles I (Sossianus Hierocles), RACh XV 103-109; M. Forrat, Introduction, w: SCh 333, Paris 1986, 11-20, 44-46; T.D. Barnes, Sossianus Hierocles and the Antecedents of the „, Great Persecution”, „Harvard Studies in Classical Philology" 80 (1976) 239-252; M. Dzielska, Apolloniusz z Tiany. Legenda i rzeczywistość, Kraków 1983, 115-117.

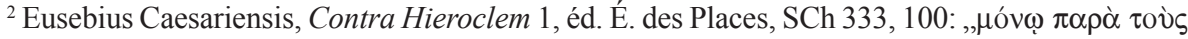

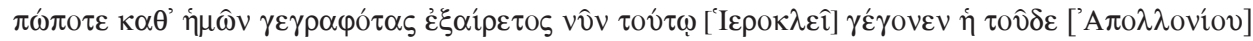

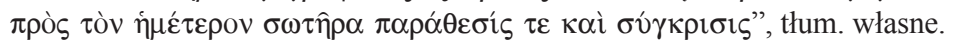


w dotychczasowych atakach na chrześcijaństwo i dlatego domagało się specjalnej odpowiedzi polemicznej z jego strony ${ }^{3}$.

Wydaje się, że cesarski namiestnik Bitynii miał świadomość kryzysu tradycyjnej filozofii i religii grecko-rzymskiej, którą sam reprezentował, i zarazem rosnącego znaczenia chrześcijaństwa oraz jego Założyciela. Jako przedstawiciel i obrońca świata pogańskiego, a jednocześnie wróg nowej religii, pragnął zatem w celach propagandowych wyeksponować w swoim dziele jakąś wyróżniającą się wśród pogan osobistość, aby w ten sposób przeciwstawić się fascynacji postacią Jezusa Chrystusa oraz przekazom o jego niezwykłych czynach i nauczaniu.

Przedstawione powyżej przypuszczenia znajdują potwierdzenie w relacji Euzebiusza, według której Hierokles najpierw wymienił ze starożytnej historii Aristeasa z Prokonnesos i Pitagorasa jako przykłady ludzi odznaczających się

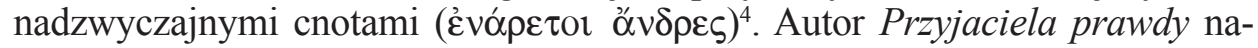
wiązał w ten sposób do argumentu historycznego, który ponad wiek wcześniej zastosował inny przeciwnik chrześcijaństwa, Celsus, w swoim Prawdziwym sło-

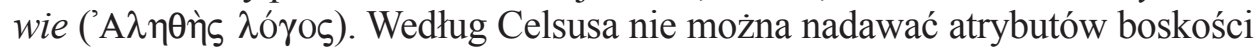
Jezusowi, ponieważ nie stanowił on nawet jakiegoś szczególnego przypadku wśród wyjątkowych postaci z dziejów greckiej religii i jako cudotwórca należał co najwyżej do całego szeregu ludzi obdarzonych charyzmatycznymi zdolnościami. W tym kontekście autor Prawdziwego słowa wymieniał między innymi właśnie postaci Aristeasa i Pitagorasa ${ }^{5}$.

Jednakże, jak relacjonuje dalej Euzebiusz, Hierokles uznał przykłady tych ludzi z historii za zbyt archaiczne, aby je zestawiać z Jezusem, i dlatego do swojego porównania wprowadził współczesną Chrystusowi postać Apoloniusza, a w jej prezentacji oparł się głównie na Żywocie Apoloniusza z Tiany

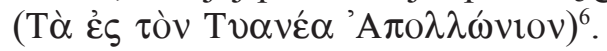

Dzieło to, zaliczane obecnie do gatunku romansu antycznego odpowiadającego dzisiejszej powieści, zostało napisane prawie sto lat wcześniej (ok. 220) przez Flawiusza Filostrata, wybitnego przedstawiciela kulturowego prądu ,drugiej sofistyki”. Tytułowy bohater, wędrowny mędrzec i zwolennik pitagoreizmu z I w. po Chr., został ukazany tutaj jako „boski mąż” ( $\theta \varepsilon \hat{\imath} о \varsigma$ ảví $\rho$ ) - ulubieniec bogów przewyższający mądrością innych filozofów, wielki asceta i cudotwórca, strażnik moralności i tradycyjnej religii grecko-rzymskiej, który dokonywał wielu wspaniałych dzieł, podróżował po całym ówczesnym

${ }^{3}$ Por. tamże, SCh 333, 98-100.

${ }^{4}$ Tamże 2, SCh 333, 100-102. Aristeas z Prokonnesos, osnuty legendą sługa boga Apollona i poeta epicki z VII lub VI w. prz. Chr., po śmierci miał się pojawiać i znikać w różnym czasie i w różnych miejscach; por. Słownik pisarzy antycznych, red. A. Świderkówna, Warszawa 1990, 88; P. Grimal, Stownik mitologii greckiej i rzymskiej, red. wyd. pol. J. Łanowski, tłum. M. Bronarska B. Górska - A. Nikliborc - J. Sachse - O. Szarska, Wrocław 1997³, 42.

${ }^{5}$ Por. Origenes, Contra Celsum I 16; 32; II 55; III 3; 26; IV 97; V 41.

${ }^{6}$ Por. Eusebius Caesariensis, Contra Hieroclem 2, SCh 333, 102-104. Zob. Speyer, Hierokles, s. 106; Forrat, Introduction, s. 44-46; Dzielska, Apolloniusz z Tiany, s. 72. 
cywilizowanym świecie, spotykał się z największymi władcami i najznakomitszymi mędrcami swojej epoki, a po licznych perypetiach odszedł z tego świata, wstępując prosto do nieba ${ }^{7}$.

$\mathrm{Z}$ tak barwnie przedstawionej w romansie Filostrata postaci mędrca z Tiany Hierokles chciał uczynić przeciwwagę dla rosnącej popularności Chrystusa i jego zwolenników. Przeciwstawiając sobie te znaczące osobistości świata pogańskiego i chrześcijańskiego, skoncentrował się przede wszystkim na ich działalności taumaturgicznej, a celem konfrontacji Apoloniusza z Chrystusem było ukazanie, że ten pierwszy dokonał podobnych albo nawet większych rzeczy, chociaż wcale nie uważał się za boga ${ }^{8}$. Zamiary Hieroklesa odniosły w pewnym sensie spodziewany przez niego skutek, ponieważ jego traktat stał się przyczyną znacznego ożywienia zainteresowań postacią Apoloniusza9 ${ }^{9}$.

W tym kontekście zastanawia zacytowane wyżej stwierdzenie Euzebiusza dotyczące oryginalności autora Przyjaciela prawdy w dokonanym przez niego porównaniu. Pojawia się mianowicie wątpliwość, czy Hierokles rzeczywiście był nowatorem w użyciu postaci Tianejczyka w polemice antychrześcijańskiej, skoro prawie wiek dzieli traktat namiestnika Bitynii od ukazania się Żywotu Apoloniusza z Tiany. Dzieło Filostrata, pełne narzucających się podobieństw czy wręcz świadomych aluzji do Ewangelii ${ }^{10}$, mogło przecież stać się

\footnotetext{
${ }^{7}$ Najnowsze wydanie tekstu oryginalnego dzieła Filostrata: Philostratus, The Live of Apollonius of Tyana, ed. Ch.P. Jones, LCL 16-17, Cambridge (Mass.) - London 2005. Polskie thumaczenia: Flawiusz Filostratos, Żywot Apolloniusza z Tiany, tłum. I. Kania, przedm. M. Dzielska, Kraków 1997; Flawiusz Filostratos, Żywot Apolloniosa z Tyany, tłum., wstęp i kom. M. Szarmach, Toruń 2012². O Flawiuszu Filostracie i jego twórczości, oprócz wstępów do podanych wyżej pozycji, zob. też: R. Popowski, Starożytny przewodnik po neapolitańskiej pinakotece, w: Filostrat Starszy, Obrazy, thum., wstęp i kom. R. Popowski, Warszawa 2004, 13-21; D. Del Corno, Introduzione, w: Filostrato, Vita di Apollonio di Tiana, a cura di D. Del Corno, Biblioteca Adelphi 82, Milano 20044, 11-33; J.J. Flinterman, Power, „Paideia” \& Pythagoreanism. Greek Identity, Conceptions of the Relationship between Philosophers and Monarchs and Political Ideas in Philostratus ', Life of Apollonius", Amsterdam 1995, 5-28; G. Anderson, Philostratus. Biography and Belles Lettres in the Third Century A.D., London 1986. Na temat obrazu Apoloniusza w dziele Filostrata zob. A. Tondera, L'immagine del ,santo” pagano nella figura di Apollonio di Tiana e la sua valutazione da parte cristiana, SACh NS 13, Katowice 2012, 13-108.

${ }^{8}$ Por. Lanctantius, Divinae institutiones V 3, 7, éd. P. Monat, SCh 204, Paris 1973, 140-142: „Voluit ostendere Apollonium vel paria vel etiam maiora fecisse”. Zob. tamże V 3, 8-10. 16, SCh 204, 142-144.

${ }^{9}$ Por. Dzielska, Apolloniusz z Tiany, s. 10, 71-73, 117 i 140-141.

${ }^{10}$ Mimo tych wyraźnych podobieństw do ksiagg Nowego Testamentu nie ma jednak w dziele Filostrata żadnej wzmianki ani o Chrystusie, ani o chrześcijanach. Współczesne prace, które zajmują się analizą zależności i związków Żywotu Apoloniusza z Tiany z literaturą nowotestamentalną, opierają się głownie na metodzie badań historii form literackich (Formgeschichtliche Forschung), zob. np. F.Ch. Baur, Drei Abhandlungen zur Geschichte der alten Philosophie und ihres Verhältnisses zum Christentum, Leipzig 1876; D. Esser, Formgeschichtliche Studien zur hellenistischen und zur frühchristlichen Literatur unter besonderer Berücksichtigung der vita Apollonii des Philostrat und der Evangelien, Bonn 1969; G. Petzke, Die Traditionen über Apollonius von Tyana und das Neue Testament, Studia ad Corpus Hellenisticum Novi Testamenti 1, Leiden 1970; E. Koskenniemi, Apol-
} 
wcześniej idealnym źródłem dla polemistów pogańskich, aby przeciwstawić Chrystusowi postać „boskiego męża”, tak bardzo wychwalaną przez uczonego sofistę. Ponadto źródła historyczne potwierdzają, że w III w. istniał już kult Apoloniusza, któremu poświęcano świątynie i posagi w miastach z nim związanych ${ }^{11}$. Rodzi się zatem pytanie, czy mędrzec z Tiany nie był już wcześniej wysunięty jako godny przeciwnik Jezusa Chrystusa w toczących się sporach między poganami i chrześcijanami?

2. Teksty przypisywane Porfiriuszowi. Pojawienie się powyższej wątpliwości uzasadniają również nowożytne badania związane z twórczością Porfiriusza, słynnego przeciwnika chrześcijaństwa i przedstawiciela filozofii neoplatońskiej z 2. poł. III i początku IV w. Zdają się one właśnie wskazywać, że już przed Hieroklesem wykorzystywano osobę Apoloniusza w polemice antychrześcijańskiej. Interesująca nas kwestia dotyczy głównie dzieła Porfiriusza

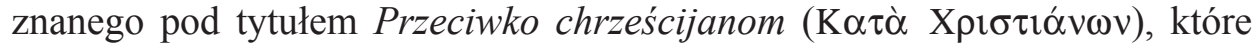
nie zachowało się do naszych czasów, a obecnie próbuje się je zrekonstruować na podstawie różnych fragmentów, cytowanych w dziełach polemizujących

lonios von Tyana in der neutestamentlichen Exegese. Forschungsbericht und Weiterführung der Diskussion, Tübingen 1994; K. Berger, Hellenistische Gattungen im Neuen Testament, ANRW II 25/2, Berlin - New York 1984, 1031-1432 i 1831-1885; H.C. Kee, Aretalogy and Gospel, JBL 92 (1973) $\mathrm{nr} 3$, 402-422; M.J. Lagrange, Les Légendes pythagoriennes et l'Évangile, RB 46 (1937) nr 1, 5-28; R. Söder, Die apokryphen Apostelgeschichten und die romanhafte Literatur der Antike, Würzburger Studien zur Altertumswissenschaft 3, Stuttgart 1932; Actes apocryphes des apôtres. Christianisme et monde païen, éd. F. Bovon i inni, Publications de la Faculté de théologie de l'Université de Genève 4, Genève 1981, 161-221. Chociaż pojawiły się opinie, że dzieło Filostrata jest jakimś rodzajem antyewangelii (por. Del Corno, Introduzione, s. 47 i nota 66 z dalszymi odnośnikami; S. Borzì, L'accostamento fra Apollonio di Tiana e Cristo, „Laós” 8 (2001) nr 1, 20 i nota 4; J.S. Phillimore, Introduction, w: Philostratus, In Honour of Apollonius of Tyana, transl. by J.S. Phillimore, t. 1, Oxford 1912, xv, nota 2; T. Zieliński, Religia Cesarstwa Rzymskiego, Toruń 2000, 305-306), współcześni badacze skłaniają się jednak ku wykluczeniu hipotezy, jakoby zamierzeniem autora było nakreślenie wizerunku pogańskiego „boskiego męża” w celu przeciwstawienia go Chrystusowi. Jednakże kwestia korzystania przez Filostrata z pism chrześcijańskich czy to kanonicznych, czy to apokryficznych w kompozycji Żywotu Apoloniusza z Tiany pozostaje do dziś otwarta.

${ }^{11}$ Ostatni władca dynastii Sewerów, Aleksander (cesarz 222-235), miał posiadać w swoim lararium, oprócz wizerunków ubóstwionych cesarzy i swoich przodków, także wizerunki pewnych animae sanctiores, a wśród nich Apoloniusza, Chrystusa, Abrahama i Orfeusza, por. Historia Augusta. Alexander Severus 29, 2 = Apollonius, Testimonia 28, ed. Ch.P. Jones, w: Philostratus, Apollonius of Tyana, t. 3: Letters of Apollonius. Ancient Testimonia. Eusebius's Reply to Hierocles, LCL 458, Cambridge (Mass.) - London 2006, 118; Del Corno, Introduzione, s. 35. Na temat kultu Apoloniusza w miastach z nim związanych i o tzw. Epigramie z Adana, zob. Petzke, Die Traditionen über Apollonius, s. 19-36; Dzielska, Apolloniusz z Tiany, s. 39-63; M. Forrat, Notes complémentaires, w: SCh 333, 215-219; S. Borzì, Apollonio di Tiana: da ,santo pagano” ad antagonista di Cristo, „Laós” 5 (1998) nr 2, 87-91; Apollonius, Testimonia 41, LCL 458, 130-131; Ch.P. Jones, An epigram of Apollonius of Tyana, „Journal of Hellenic Studies” 100 (1980), 190-194; E.L. Bowie, Apollonius of Tyana: Tradition and Reality, ANRW II 16/2, Berlin - New York 1978, 1687-1688. 
z nim autorów chrześcijańskich ${ }^{12}$. Okazuje się bowiem, że trzy fragmenty tradycyjnie przypisywane Porfiriuszowi ${ }^{13}$ wymieniają imię Apoloniusza z Tiany. Pierwszy fragment zachowany został w homilii Hieronima do jednego z Psalmów:

„Powie ktoś: «Wszystko to uczynili z żądzy zysku». Tak właśnie twierdzi Porfiriusz: «Ludzie prości i biedni, którzy niczego nie mieli, za pomocą sztuk magicznych sprawiali jakieś cuda. Nie jest jednak czymś nadzwyczajnym dokonywanie cudów. Przecież magowie w Egipcie także uczynili cuda przeciwko Mojżeszowi. Czynili je również i Apoloniusz, i Apulejusz; a dokonali niezliczonych cudów»"14.

W tym fragmencie Porfiriusz z pogardą odnosi się do cudotwórczej działalności uczniów Chrystusa (w szerszym kontekście komentarza Hieronima chodzi głównie o Piotra i Pawła), stwierdzając, że dokonali wprawdzie pewnych cudów, ale ,za pomocą sztuk magicznych (magicis artibus)”, a uprawianie magii wynikało z ich nieokrzesania i biedy oraz miało na celu osiągnięcie materialnej korzyści. Według pogańskiego autora dokonywanie cudów nie jest wcale czymś wyjątkowym (Non est autem grande facere signa), ponieważ tacy ludzie jak Apoloniusz i Apulejusz czynili ich bardzo wiele (infinita signa fecerunt). W wypowiedzi Porfiriusza podkreślony jest zatem aspekt taumaturgiczny działalności Apoloniusza; porównanie nie dotyczy jednak bezpośrednio osoby Chrystusa, ale odnosi się raczej do misji apostołów. Pochodzenie tego cytatu nie podlega dyskusji, ponieważ Hieronim wymienia imię Porfiriusza jako autora tych słów.

Kolejne istotne dla nas dwa fragmenty zamieszczone są w polemicznym dziele Makarego Magnezjanina (utożsamianego z biskupem Makarym

${ }^{12} \mathrm{O}$ tych próbach zob. T.D. Barnes, Porphyry „Against the Christians”: Date and the Attribution of Fragments, JTS 24 (1973) 424-430; A. Kofsky, Eusebius of Caesarea against Paganism, Jewish and Christian Perspectives Series 3, Leiden - Boston - Köln 2000, 17-35; F. Ruggiero, Szaleństwo chrześcijan. Poganie wobec chrześcijaństwa w pierwszych pięciu wiekach, thum. E. Łukaszyk, Kraków 2007, 127-157.

${ }^{13} \mathrm{~W}$ badaniach nad dziełem Przeciwko chrześcijanom klasyczną pozycją jest praca A. von Harnacka (Porphyrius ,, Gegen die Christen”, 15 Bücher. Zeugnisse, Fragmente und Referate, Abhandlungen der Königlich Preussischen Akademie der Wissenschaften. Philosophisch-Historische Klasse 1, Berlin 1916), gdzie zostało zebranych 97 fragmentów przypisywanych Porfiriuszowi, a zachowanych w pismach późniejszych autorów. Harnack uważa tutaj antychrześcijańskie pismo Porfiriusza za największe i najbardziej uczone dzieło, jakie w starożytności zostało napisane przeciwko chrześcijaństwu. Zob. też ostatnie prace, które bazują na dziele Harnacka: Porfirio, Discorsi contro i cristiani, a cura di C. Mutti, Padova 1977; R.M. Berchman, Porphyry Against the Christians, Studies in Platonism, Neoplatonism and the Platonic Tradition 1, Leiden - Boston 2005; Porfirio, Contro i cristiani. Nella raccolta di Adolf von Harnack con tutti i nuovi frammenti in appendice, introd., trad., note e apparati di G. Muscolino, Milano 2009; Porfiriusz z Tyru, Przeciw chrześcijanom, tłum., wstęp i kom. P. Ashwin-Siejkowski, Kraków 2006.

${ }^{14}$ Hieronymus, Tractatus LIX in Psalmos 81, 225-230, ed. G. Morin, CCL 78, Turnholti 1958, 89, tłum. własne $=$ Porphyrius, Contra Christianos fragm. 4, ed. Harnack, s. 27-29. 
z Magnezji) pod dosyć tajemniczym tytułem: Odpowiedź na krytykę albo Jednorodzony do Hellenów ('A tej apologii chrześcijaństwa, napisanej około 400 r., wplótł je w fikcyjną dysputę między sobą samym i pewnym pogańskim adwersarzem na temat zasad wiary chrześcijańskiej. Ów wrogi chrześcijaństwu filozof miałby właśnie prezentować poglądy Porfiriusza, zawarte w jego dziele Przeciwko chrześcijanom $^{16}$.

W jednej z wypowiedzi pogańskiego rozmówcy wysoko ocenione są koncepcje filozoficzne Apoloniusza:

„W innym miejscu znajduje się pewne wątpliwe powiedzenie Chrystusa: «Strzeżcie się, żeby was kto nie zwiódł. Wielu bowiem przyjdzie pod moim imieniem i będą mówić: 'Ja jestem Mesjaszem'. I wielu w błąd wprowadzą». I oto upłynęło ponad trzysta lat i nikt taki się nie pojawił. Chyba że oczywiście mówicie o Apoloniuszu z Tiany, mężu ozdobionym wszelaką filozofią. Lecz nie ma nikogo innego. A wszak zapowiadał on pojawienie się nie jednego, lecz «powstanie» wielu" ${ }^{17}$.

Wychwalając Apoloniusza, filozof pogański nadaje mu tutaj epitet „męża

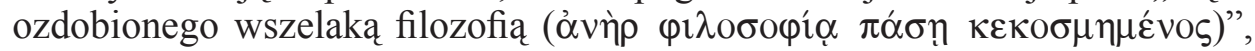
nie zauważamy jednak bezpośredniego porównania między Apoloniuszem a Chrystusem, mimo że obydwaj są wymienieni. W tym epitecie i w całym

${ }^{15}$ Ostatnie wydanie krytyczne dzieła Makarego z obszernym wstępem i komentarzami: Macarios de Magnésie, Le Monogénès, Introd. générale, éd. critique, trad. et comm. par R. Goulet, t. 1-2, Paris 2003; na temat tego dzieła zob. też R. Waelkens, L'économie, thème apologétique et principe herméneutique dans l',,Apocriticos"' de Macarios Magnès, Recueil de Travaux d'Histoire et de Philologie 6, z. 4, Louvain 1974.

${ }^{16}$ Ponieważ w apologetycznym piśmie Makarego nie ma wyraźnego wskazania imienia autora cytowanych wypowiedzi, kwestia źródła tych fragmentów pozostaje wciąż sporna. Teza Harnacka o ich pochodzeniu wprost z dzieła Porfiriusza Przeciwko chrześcijanom została podważona

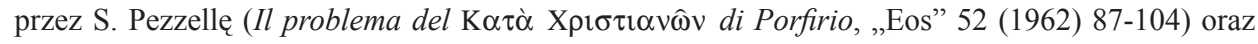
przez T.D. Barnesa (Porphyry „Against the Christians”, s. 428-430). Pezzella twierdzi, że apologia Makarego zawiera raczej mały zbiór różnych polemik antychrześcijańskich, Barnes natomiast dopuszcza możliwość zamieszczenia w tej apologii argumentacji Porfiriusza, ale jedynie w sposób niebezpośredni, czyli od późniejszego autora bądź też autorów, którzy korzystali z dzieła Przeciwko chrześcijanom. Wraz z odrzuceniem twierdzeń Harnacka nie udowodniono jednak innych hipotez o wykorzystaniu w dziele Makarego wypowiedzi Hieroklesa, Jamblicha lub Juliana Apostaty; por. Waelkens, L'économie, s. 8-9; Speyer, Hierokles, s. 108; E. De Palma Digeser, Porphyry, Julian or Hierocles? The Anonymous Hellene Makarios of Magnes' Apokritikos, JTS 53 (2002) 466-502; Berchman, Porphyry Against the Christians, s. 5, nota 26 oraz s. 120-121; P. Ashwin-Siejkowski, Wstę, w: Porfiriusz z Tyru, Przeciw chrześcijanom, s. 7-15.

${ }^{17}$ Macarius Magnes, Apocriticus IV 5, 2, ed. Goulet, t. 2, s. 246-247 = Porphyrius, Contra Christianos fragm. 60, ed. Harnack, s. 83, tłum. Ashwin-Siejkowski, s. 133. Harnack uważa wyrażenie

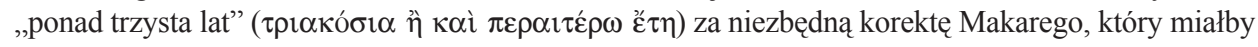
w ten sposób dostosować wypowiedź Porfiriusza do potrzeb prezentowanej dysputy i do swojego kontekstu historycznego. W rzeczywistości, jak przypuszcza Harnack, Porfiriusz musiałby napisać „,ponad

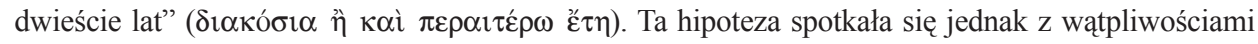
i sprzeciwem, por. Porfirio, Contro i cristiani, s. 322-323, nota 2 oraz s. 496-497, nota 291. 
kontekście wypowiedzi można się jedynie dopatrywać jakiejś obrony Tianejczyka przed ewentualnymi oskarżeniami ze strony chrześcijan, na podstawie których miałby on być uważany za antychrysta ${ }^{18}$. Cytat ten, jak zresztą i poprzedni, stanowią raczej krótkie wzmianki o charakterze ogólnym i nie odnoszą się wprost do opowiadań zawartych w dziele Filostrata.

Szczególnie interesujący jest jednak następny fragment przypisywany Porfiriuszowi, który znajduje się w tym samym dziele Makarego:

„Dlaczego Chrystus nie powiedział nic godnego człowieka mądrego i boskiego, kiedy został doprowadzony do arcykapłana i do namiestnika rzymskiego? Mógł przecież pouczyć swego sędziego, jak i obecnych tam ludzi, jak stać się lepszymi ludźmi. Dlaczego raczej pozwolił na biczowanie, oplucie i ukoronowanie cierniami? Dlaczego nie postąpił tak jak Apoloniusz, który odważnie odpowiedział cesarzowi Domicjanowi, następnie zniknął z pałacu, a wkrótce był widziany przez wielu w mieście Dikajarchia, teraz zwanym Puteoli? Nawet jeśli cierpienie Chrystusa miało miejsce zgodnie z Bożym planem, nawet jeśli miał On cierpieć karę - to przynajmniej mógłby przyjąć cierpienie z odwagą $\mathrm{i}$ wypowiedzieć do Piłata i sędziów słowa mocy i mądrości, zamiast dać zrobić z siebie pośmiewisko niczym uliczny prostak"19.

Bezimienny filozof wrogi chrześcijaństwu potępia w tej wypowiedzi zachowanie Chrystusa podczas jego procesu. Jezus jest krytykowany za to, że pozwolił upokorzyć się wobec wszystkich i nie potrafił wypowiedzieć nawet

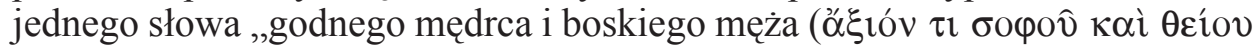

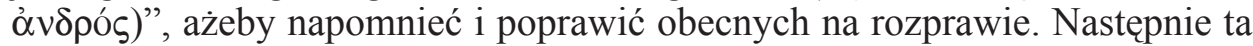
uległa i milcząca postawa Chrystusa wobec sędziów zostaje zestawiona z zachowaniem Apoloniusza, który w czasie swojego procesu nie pozwolił się poniżyć Domicjanowi; po śmiałej odpowiedzi ( $\mu \varepsilon \tau \grave{\alpha} \pi \alpha \rho \rho \eta \sigma i \alpha \varsigma)$ udzielonej cesarzowi zniknął z sali rozpraw i tego samego dnia pojawił się w Dikajarchii. To zestawienie prowadzi przeciwnika chrześcijaństwa do wniosku, że Chrystus nie powinien był bezwolnie przyjmować swej męki bez wystapienia wcześniej z odważną przemową, którą w słowach stanowczych i mądrych

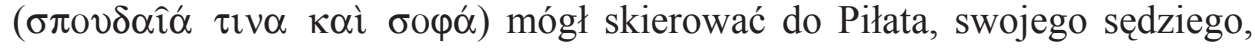
zamiast pozwolić na publiczne znieważanie siebie.

W tym krótkim fragmencie można zauważyć zarówno porównanie Apoloniusza z Chrystusem, jak i wykorzystanie w tym celu jednego z wydarzeń opisanych przez Filostrata ${ }^{20}$. W porównaniu zachowań obu tych postaci podczas ich procesu akcent został położony nie tyle na cudowne zniknięcie Apoloniusza

${ }^{18}$ Por. Forrat, Introduction, s. 51; R. Goulet, Appendice exégétique, w: Macarios de Magnésie, Le Monogénès, t. 2, s. 409. Na temat wysokiej oceny poglądów filozoficznych Apoloniusza ze strony Porfiriusza zob. Dzielska, Apolloniusz z Tiany, s. 99-102.

${ }_{19}^{19}$ Macarius Magnes, Apocriticus III 1, 1-2, ed. Goulet, t. 2, s. 72-73 = Porphyrius, Contra Christianos fragm. 60, ed. Harnack, s. 84-85, thum. Ashwin-Siejkowski, s. 77-79.

${ }^{20}$ Por. Philostratus, Vita Apollonii VIII 5. 8 i 10, LCL 17, 318-323 i 382-387. 
sprzed trybunału cesarskiego, ile raczej na jego heroiczna postawę, zgodna z greckim ideałem bohatera i filozofa, który w żadnych okolicznościach nie pozwala się upokorzyć, a sam jest zawsze gotów do pouczenia innych. Całkowicie odmiennie w tym kontekście wypada poniżony i milczący Chrystus, którego postawa wobec sędziów myślicielowi pogańskiemu wydaje się hańbiąca.

$\mathrm{Na}$ końcu swojej wypowiedzi ucieka się on jeszcze do inwektywy pod adresem Chrystusa, którego zachowanie porównuje do ,jakiegoś prosta-

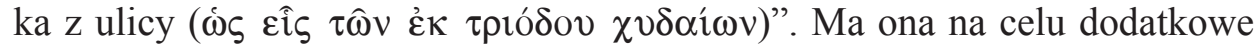
podkreślenie sprzeczności, jaka ujawnia się - zdaniem antychrześcijańskiego rozmówcy - w scenie sądu nad Chrystusem: Jezus podawał się przecież za kogoś wielkiego, za Bożego Pomazańca, który poprzez przyjęcie cierpienia miał wypełnić plany Boże, tymczasem w momencie próby, pozwalając się poniżyć i ośmieszyć (íßpı $\theta \hat{\eta} v \alpha \imath$ ), okazał się właśnie kimś nieznaczącym, trywialnym, z pewnością nie herosem $w$ rozumieniu greckim ${ }^{21}$.

Od Laktancjusza wiemy, że ta sama scena procesu Apoloniusza przed Domicjanem znalazła się również w porównaniu Tianejczyka z Chrystusem, które przeprowadził Hierokles w Przyjacielu prawdy. Cudowne zniknięcie Apoloniusza sprzed trybunału, gdy cesarz zamierzał go ukarać, miało być tutaj przejawem wyższości męża z Tiany nad pojmanym i przybitym do krzyża Chrystusem. Przez przywołanie tego wydarzenia z dzieła Filostrata Hierokles zamierzał ponadto wykazać „pychę” (insolentia) Chrystusa, który ogłosił siebie bogiem, w zestawieniu ze skromniejszą postawą (verecundior) Apoloniusza, który nie przypisywał sobie takiego tytułu, chociaż dokonał większych rzeczy ${ }^{22}$.

W obecnym stanie wiedzy pozostaje wciąż wattpliwe, czy autorem wypowiedzi z dwóch analizowanych fragmentów dzieła Makarego był rzeczywiście Porfiriusz $^{23}$. Poddano także ponownie pod dyskusję tradycyjnie przyjmowaną datację jego antychrześcijańskiego pisma: być może zostało ono napisane nie ok. 270 r., jak wcześniej uważano, ale dopiero na początku IV wieku ${ }^{24}$. Jest zatem możliwe, że powstało równocześnie z traktatem Hieroklesa albo nawet po nim; w takim przypadku pierwszeństwo chronologiczne porównania Apoloniusza z Chrystusem, przeprowadzonego przez namiestnika Bitynii, nie podlegałoby dyskusji.

3. Topos porównania Apoloniusza z Chrystusem. Liczne wattpliwości w tym względzie skłaniają do przypuszczenia, że należy brać pod uwagę

\footnotetext{
${ }^{21}$ Por. Forrat, Introduction, s. 47-48 i 52; Porfiriusz z Tyru, Przeciw chrześcijanom, s. 79, nota 5.

${ }^{22}$ Por. Lactantius, Divinae institutiones V 3, 9-10, SCh 204, 142. Zob. Tondera, „Przyjaciel prawdy" Sossianusa Hieroklesa, s. 312.

${ }^{23}$ Por. nota 16.

${ }^{24}$ Argumenty dla takiej datacji Przeciwko chrześcijanom prezentuje T.D. Barnes (Porphyry „Against the Christians”, s. 433-442), por. A. Meredith, Porphyry and Julian Against the Christians, ANRW II 23/2, Berlin - New York 1980, 1126; De Palma Digeser, Porphyry, Julian or Hierocles?, s. 478; Ashwin-Siejkowski, Wstęp, s. 16-20.
} 
większą liczbę pism wrogich chrześcijaństwu niż ta, która nam jest obecnie znana. Taką hipotezę potwierdza informacja Laktancjusza o pewnym filozofie, który na początku ,wielkiego prześladowania” publicznie przedstawiał w Nikomedii swoje antychrześcijańskie dzieło razem z Hieroklesem, a którego obecnie trudno zidentyfikować25. Również w traktacie Euzebiusza Przeciwko Hieroklesowi pojawia się wzmianka sugerująca, że poza Celsusem istnieli jeszcze inni polemiści pogańscy, którzy przed Hieroklesem mieli wystąpić przeciwko wierze chrześcijańskiej na piśmie ${ }^{26}$. Okres tetrarchii był widocznie bogatszy w tego rodzaju literaturę, niż wynikałoby to z ilości zachowanych źródeł ${ }^{27}$.

Nie negując stwierdzenia Euzebiusza o nowatorstwie Hieroklesa, można ponadto wysunąc hipotezę, że w pismach polemicznych wcześniejszych od Przyjaciela prawdy, jak również w nurcie ludowym, mogła być już obecna tendencja do przeciwstawienia Chrystusowi Apoloniusza z Tiany. Ta tendencja nie nosiła jednak znamion systematycznych opracowań opartych na solidnie zbudowanych argumentach, na co zdają się wskazywać przedstawione fragmenty, za których autora uważa się Porfiriusza. Ponadto fakt wykorzystania tego samego motywu zarówno przez Hieroklesa, jak i w analizowanej wcześniej wypowiedzi przypisywanej Porfiriuszowi, zdaje się sugerować, że zestawianie Apoloniusza z Chrystusem, a zwłaszcza ich procesów, bohaterstwa i siły jednego oraz poniżenia i słabości drugiego, stanowiło pewien topos $\mathrm{w}$ polemice ze strony pogańskiej w 2 . poł. III wieku ${ }^{28}$.

Taka hipoteza znajduje potwierdzenie również w drobnej wskazówce o charakterze lingwistycznym pochodzącej z zacytowanego na początku tekstu Euzebiusza. Otóż pisząc o oryginalności dokonanego przez Hieroklesa ,zestawie-

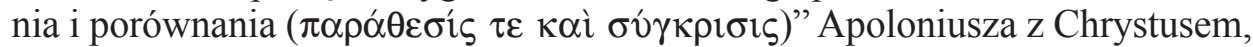

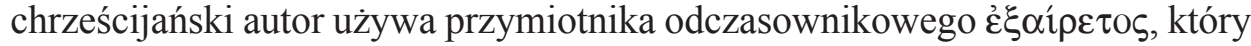
w tym kontekście mógłby znaczyć: „,wybrany”, „wyselekcjonowany”, „wyjątkowy”, „nadzwyczajny”, „specjalny”29. Wobec tego stwierdzenie Euzebiusza

${ }^{25}$ Por. Lactantius, Divinae institutiones V 2, 2-11, SCh 204, 134-138. C. Moreschini (Storia della filosofia patristica, Letteratura cristiana antica 1, Brescia 2004, 253) przypuszcza, że tym anonimowym filozofem mógł być sam Porfiriusz, jednak T.D. Barnes (Porphyry „, Against the Christians", s. 437-439) odrzuca taką hipotezę.

${ }^{26}$ Por. Eusebius Caesariensis, Contra Hieroclem 1, SCh 333, 98-100 (a zwłaszcza wyrażenie:

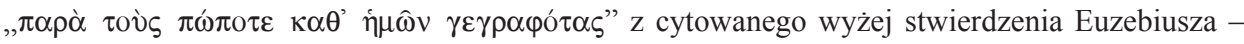
zob. nota 2).

${ }^{27}$ Por. Speyer, Hierokles, s. 108.

${ }^{28}$ Por. M. Szarmach, Pismo Euzebiusza z Cezarei: „Contra Hieroclem”, „Acta Universitatis Nicolai Copernici”, Historia 27, Nauki Humanistyczno-Społeczne 254 (1992) 128; AshwinSiejkowski, Wstęp, s. 16; Borzì, L'accostamento, s. 22-24; Forrat, Introduction, s. 49 i 53. Do tego motywu nawiązali później Hieronim (Contra Joannem Hierosolymitanum 34, PL 23, 387) i PseudoAmbroży (De Trinitate 29, PL 17, 540).

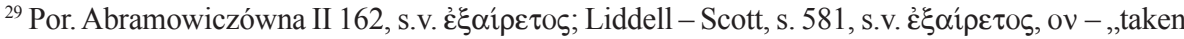
out”, and so, 1. „picked out”, ,chosen”, ,choice”, 2. „excepted”, 3. „,special”, ,,singular”, ,remarkable”. 
o oryginalności porównania Hieroklesa nie neguje możliwości wcześniejszych prób zestawiania Apoloniusza z Chrystusem, a nawet wydaje się je zakładać.

Hierokles w tych wcześniejszych dążeniach mógł znaleźć gotowy materiał lub sam pomysł dla swojego porównania, opracować wszystko, wykorzystując do tego celu dzieło Filostrata, i potem przedstawić w systematycznym wykładzie. Oryginalności tej części jego traktatu należałoby więc szukać w solidnej argumentacji i systematycznym opracowaniu, które domagały się specjalnej odpowiedzi polemicznej ze strony chrześcijańskiej ${ }^{30}$. Zarówno Laktancjusz jak i Euzebiusz z Cezarei doskonale rozumieli, iż to dzieło wrogie chrześcijaństwu nie powinno pozostać bez ich reakcji, gdyż dzięki tak dopracowanej propagandzie Hieroklesa postać Apoloniusza mogła stać się groźnym konkurentem Chrystusa w istotnym momencie dla rozwoju wiary chrześcijańskiej.

\section{ORIGINALITY OF HIEROCLES' COMPARISON BETWEEN APOLLONIUS OF TYANA AND CHRIST}

(Summary)

Sossianus Hierocles, governor of Bithynia and adviser of the emperor Diocletian, at the beginning of the "great persecution" of the Christians published his propagandistic writing under the title The Lover of Truth, in which he drew a comparison between Apollonius of Tyana and Christ. In the apologetic treatise of Eusebius of Caesarea Against Hierocles we find a statement, that this comparison was something new in the hitherto existing attacks of the pagan intellectuals on Christianity and demanded a polemic response from the Christian part. Modern studies regarding the works of Porphyry, famous enemy of the Christians and exponent of the Neo-Platonic philosophy, seem to indicate that even before Hierocles the personage of Apollonius was used in the anti-Christian polemics and was confronted with Christ. The present article try to explain, what the originality of Hierocles' comparison, testified by Eusebius, consisted in.

Key words: comparison between Apollonius of Tyana and Christ, Sossianus Hierocles, The Lover of Truth, Porphyry, Against the Christians, Eusebius of Caesarea, Against Hierocles.

Słowa kluczowe: porównanie Apoloniusza z Tiany z Chrystusem, Sossianus Hierokles, Przyjaciel prawdy, Porfiriusz, Przeciwko chrześcijanom, Euzebiusz z Cezarei, Przeciwko Hieroklesowi.

${ }^{30}$ Por. Forrat, Introduction, s. 53; Dzielska, Apolloniusz z Tiany, s. 116; taż, Przedmowa, w: Flawiusz Filostratos, Żywot Apolloniusza z Tiany, s. 27-28. 


\section{BIBLIOGRAFIA}

\section{Źródła}

Apollonius Tyaneus, Testimonia, ed. Ch.P. Jones, w: Philostratus, Apollonius of Tyana, t. 3: Letters of Apollonius. Ancient Testimonia. Eusebius's Reply to Hierocles, LCL 458, Cambridge (Mass.) - London 2006, 86-143.

Eusebius Caesariensis, Contra Hieroclem, éd. É. des Places, SCh 333, Paris 1986.

Hieronymus, Contra Joannem Hierosolymitanum, PL 23, 355-398.

Hieronymus, Tractatus LIX in Psalmos, ed. G. Morin, CCL 78, Turnholti 1958, 3-352.

Lanctantius, Divinae institutiones, éd. P. Monat, SCh 204, Paris 1973.

Macarius Magnes, Apocriticus, éd. R. Goulet: Macarios de Magnésie, Le Monogénès, t. 1-2, Paris 2003.

Origenes, Contra Celsum, éd. M. Borret, SCh 132, 136, 147, 150, 227, Paris 1967-1976, thum. S. Kalinkowski: Orygenes, Przeciw Celsusowi, Warszawa $1986{ }^{2}$.

Philostratus, Vita Apollonii, ed. Ch.P. Jones: Philostratus, The Live of Apollonius of Tyana, LCL 16-17, Cambridge (Mass.) - London 2005; thum. I. Kania: Flawiusz Filostratos, Żywot Apolloniusza z Tiany, Kraków 1997; tłum. M. Szarmach: Flawiusz Filostratos, Żywot Apolloniosa z Tyany, Toruń $2012^{2}$.

Porphyrius, Contra Christianos, ed. A. von Harnack, Porphyrius „, Gegen die Christen”, 15 Bücher. Zeugnisse, Fragmente und Referate, Abhandlungen der Königlich Preussischen Akademie der Wissenschaften. Philosophisch-Historische Klasse 1, Berlin 1916; ed. G. Muscolino: Porfirio, Contro i cristiani. Nella raccolta di Adolf von Harnack con tutti i nuovi frammenti in appendice, Milano 2009; tłum. włoskie: Porfirio, Discorsi contro i cristiani, a cura di C. Mutti, Padova 1977; tłum. P. Ashwin-Siejkowski: Porfiriusz z Tyru, Przeciw chrześcijanom, Kraków 2006.

Pseudo-Ambrosius, De Trinitate, PL 17, 509-546.

\section{Opracowania}

Actes apocryphes des apôtres. Christianisme et monde païen, éd. F. Bovon i inni, Publications de la Faculté de théologie de l'Université de Genève 4, Genève 1981.

Anderson G., Philostratus. Biography and Belles Lettres in the Third Century A.D., London 1986.

Ashwin-Siejkowski P., Wstęp, w: Porfiriusz z Tyru, Przeciw chrześcijanom, Kraków 2006.

BARnes T.D., Porphyry „, Against the Christians”: Date and the Attribution of Fragments, JTS 24 (1973) 424-442.

BARnes T.D., Sossianus Hierocles and the Antecedents of the „, Great Persecution”, „Harvard Studies in Classical Philology" 80 (1976) 239-252.

BAur F.Ch., Drei Abhandlungen zur Geschichte der alten Philosophie und ihres Verhältnisses zum Christentum, Leipzig 1876.

Berchman R.M., Porphyry Against the Christians, Studies in Platonism, Neoplatonism and the Platonic Tradition 1, Leiden - Boston 2005.

Berger K., Hellenistische Gattungen im Neuen Testament, ANRW II 25/2, Berlin - New York 1984.

Borzì S., Apollonio di Tiana: da „santo pagano” ad antagonista di Cristo, „Laós” 5 (1998) $\mathrm{nr}$ 2, 83-96.

Borzì S., L'accostamento fra Apollonio di Tiana e Cristo, „Laós” 8 (2001) nr 1, 19-24.

BowIE E.L., Apollonius of Tyana: Tradition and Reality, ANRW II 16/2, Berlin - New York 1978, 1652-1699. 
De Palma Digeser E., Porphyry, Julian or Hierocles? The Anonymous Hellene Makarios of Magnes' Apokritikos, JTS 53 (2002) 466-502.

Del Corno D., Introduzione, w: Filostrato, Vita di Apollonio di Tiana, a cura di D. Del Corno, Biblioteca Adelphi 82, Milano 20044, 10-57.

Dzielska M., Apolloniusz z Tiany. Legenda i rzeczywistość, Kraków 1983.

Dzielska M., Przedmowa, w: Flawiusz Filostratos, Żywot Apolloniusza z Tiany, thum. I. Kania, Kraków 1997, 5-40.

ESSER D., Formgeschichtliche Studien zur hellenistischen und zur frühchristlichen Literatur unter besonderer Berücksichtigung der vita Apollonii des Philostrat und der Evangelien, Bonn 1969.

Flinterman J.J., Power, „Paideia” \& Pythagoreanism. Greek Identity, Conceptions of the Relationship between Philosophers and Monarchs and Political Ideas in Philostratus' „Life of Apollonius”, Amsterdam 1995.

FORRAT M., Introduction, w: SCh 333, Paris 1986, 9-80.

Forrat M., Notes complémentaires, w: SCh 333, Paris 1986, 215-224.

Grimal P., Stownik mitologii greckiej i rzymskiej, red. wyd. pol. J. Łanowski, tłum. M. Bronarska - B. Górska - A. Nikliborc - J. Sachse - O. Szarska, Wrocław $1997^{3}$.

Harnack A. von, Porphyrius „, Gegen die Christen”, 15 Bücher. Zeugnisse, Fragmente und Referate, Abhandlungen der Königlich Preussischen Akademie der Wissenschaften. Philosophisch-Historische Klasse 1, Berlin 1916.

JoNes Ch.P., An epigram of Apollonius of Tyana, ,Journal of Hellenic Studies” 100 (1980) 190-194.

KeE H.C., Aretalogy and Gospel, JBL 92 (1973) nr 3, 402-422.

Kofsky A., Eusebius of Caesarea against Paganism, Jewish and Christian Perspectives Series 3, Leiden - Boston - Köln 2000.

Koskenniemi E., Apollonios von Tyana in der neutestamentlichen Exegese. Forschungsbericht und Weiterführung der Diskussion, Tübingen 1994.

LAgrange M.J., Les Légendes pythagoriennes et l'Évangile, RB 46 (1937) nr 1, 5-28.

Meredith A., Porphyry and Julian Against the Christians, ANRW II 23/2, Berlin - New York 1980, 1119-1149.

Moreschini C., Storia della filosofia patristica, Letteratura cristiana antica 1, Brescia 2004.

Petzke G., Die Traditionen über Apollonius von Tyana und das Neue Testament, Studia ad Corpus Hellenisticum Novi Testamenti 1, Leiden 1970.

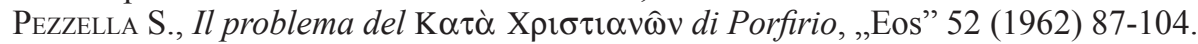

Phillimore J.S., Introduction, w: Philostratus, In Honour of Apollonius of Tyana, transl. by J.S. Phillimore, t. 1, Oxford 1912, xi-cxxviii.

Popowski R., Starożytny przewodnik po neapolitańskiej pinakotece, w: Filostrat Starszy, Obrazy, tłum., wstęp i kom. R. Popowski, Warszawa 2004, 13-87.

Ruggiero F., Szaleństwo chrześcijan. Poganie wobec chrześcijaństwa w pierwszych pięciu wiekach, tłum. E. Łukaszyk, Kraków 2007.

Stownik pisarzy antycznych, red. A. Świderkówna, Warszawa 1990.

SöDER R., Die apokryphen Apostelgeschichten und die romanhafte Literatur der Antike, Würzburger Studien zur Altertumswissenschaft 3, Stuttgart 1932.

SPeYer W., Hierokles I (Sossianus Hierocles), RACh XV 103-109.

Szarmach M., Pismo Euzebiusza z Cezarei: ,, Contra Hieroclem”, „Acta Universitatis Nicolai Copernici”, Historia 27, Nauki Humanistyczno-Społeczne 254 (1992) 127-134.

TONDERA A., L'immagine del „, santo” pagano nella figura di Apollonio di Tiana e la sua valutazione da parte cristiana, SACh NS 13, Katowice 2012. 
Tondera A., ,, Przyjaciel prawdy” Sossianusa Hieroklesa, SSHT 46 (2013) fasc. 2, 303316. WAELKens R., L'économie, thème apologétique et principe herméneutique dans l',Apocriticos” de Macarios Magnès, Recueil de Travaux d'Histoire et de Philologie 6, z. 4, Louvain 1974.

Zieliński T., Religia Cesarstwa Rzymskiego, Toruń 2000. 
